\title{
Entrepreneurship as Expectations Management
}

\section{Steven E. Phelan}

E ntrepreneurial profits flow from differences in expectations between buyers and sellers regarding the future value of resources. This article investigates whether differences in expectations can be influenced by an entrepreneur to produce greater profits. It is argued that there are several points in the entrepreneurial process where such interventions can occur and that the use of these techniques should be associated with superior wealth creation. The article also explores the ethical implications of influencing stakeholders in this way.

It is no secret in Silicon Valley that Messrs. Gates, Allen, and Ballmer of Microsoft owe their fortunes to a brilliant ruse. Back in 1980, they managed to convince IBM to purchase an operating system from Microsoft that would allegedly run on IBM's soon-to-be-released personal computer. Sadly, at the time, Microsoft did not own such an operating system, nor was the company capable of developing one in the required timeframe. Instead, Microsoft proceeded to acquire the rights to a suitable operating system from Seattle Computer Systems (SCS) for the paltry sum of $\$ 50,000$, no doubt by keeping the identity of the ultimate customer tightly concealed. The PBS documentary, Triumph of the Nerds, described it as "...the deal of the century if not the millennium...it was certainly the deal that made Bill Gates and Paul Allen multibillionaires."

While Microsoft's success will continue to inspire entrepreneurial ambitions well into the 21 st century, it is debatable whether the dominant explanation for wealth generation in strategic management, namely the resource-based perspective (Wernerfelt 1984; Barney 1991), is capable of capturing the nuances of Gates' strategy. Microsoft obviously possessed unique information and negotiation skills that IBM and SCS did not. Nevertheless, it was the way Microsoft shaped and molded the expectations of IBM and SCS that was the salient feature in the case.

Since the publication of Barney's (1986) seminal article on strategic factor markets, strategists have been aware of the important role played by expectations in profit generation. Paradoxically, while they have acknowledged the importance of expectations, strategists have given scant attention to how expectations may be strategically manipulated to extract greater profits. Few people would dispute the influence of advertisers, politicians, the media, and other "spin doctors" in shaping public opinion, attitudes, and behavior, yet the ability to shape expectations is also of fundamental importance to entrepreneurs. If we believe that expectations can be molded, manipulated, and manufactured, then the formal study of expectations management may provide fertile ground for understanding, and prescribing strategies for, entrepreneurial wealth creation.

The first section of this article examines the role of expectations in wealth creation. The second section defines expectation management, while the third section introduces a model of resource management, which makes the links to expectations management explicit and identifies targets for managerial action. In the fourth part of the article, strategies for managing expectations are considered, drawing on various theories culled from economics, psychology, and sociology.The article concludes with a consideration of the implications of expectations management for theory and practice and examines the scope for future research.

\section{Expectations and Wealth Creation}

For several decades, economists in the Austrian tradition have argued that (entrepreneurial) profits arise from differences in expectations between buyers and sellers (Schumpeter 1934; Hayek 1945; Kirzner 1973). However, an appreciation of the role of expectations in generating entrepreneurial profits only began to filter into strategic management in the early 1980s, primarily through the writings of economists such as Rumelt (1987), Teece (1986) and Nelson and Winter (1982). Ultimately, it was through the work of Barney (1986) that the relationship between expectations and profit found its clearest expression in the strategy literature.

According to Barney (1986), the value of resource ownership must be offset against the cost of acquiring that resource in a "strategic factor market." Resources become more valuable when they are rare and difficult to copy or acquire. However, in a perfectly competitive market the owner of a resource will be fully aware of the value of the resource and will ensure that the cost of acquiring the resource will exactly equal the value created by shifting the resource to its new use (or user). This is true even if the resource is to be used in combination with other resources. As long as the original owner of the resource can accurately assess its future value, she will stand to appropriate all gains from its future deployment.

There are only two situations where this will not be the case: information asymmetry and windfalls. In both cases, the seller fails to correctly anticipate the future value of a resource. In the case of information asymmetry, the buyer possesses 
information that the seller does not. This information allows the buyer to form a different expectation about the future value of the resource than the seller. If the buyer's information is accurate, the buyer will make a profit on the transaction, a profit referred to as an entrepreneurial profit by Rumelt (1987). Of course, this raises the question of why the seller was not able to acquire the same information as the buyer. One possibility is that the entrepreneur had greater insight or alertness to profit opportunities than the seller (Kirzner 1973).

The second case of "strategic factor market" failure occurs when neither the buyer, nor the seller, correctly anticipates the future value of a resource. In this case, the value of the resource changes favorably after the buyer acquires it. This is known as a "windfall profit" in economics. By definition, windfall profits cannot be planned (although windfall events can often have a profound influence on the future strategic development of a company as witnessed by Microsoft's unexpected opportunity to sell an operating system to IBM).

Barney's (1986) ideas have been challenged by Dierickx and Cool (1989), who have argued that certain resources, such as culture and reputation, cannot be traded in "strategic factor markets". Instead, these nontradable assets accumulate over time and cannot be alienated from the firm (although they may be transferred when the entire firm is bought or sold). Strategic management, in Dierickx and Cool's opinion, involves both growing nontradable assets and acquiring resources in strategic factors markets.

Barney (1989) has countered by arguing that nontradable resources, such as cultures and reputations, are metaresources that arise from the interactions between factors in the firm over time. In a perfect market, the cost of these resources in the strategic factor market would include the future value to be derived from the creation of metaresources, such as reputation. If not, either the firm had better information about the future value of a reputation when assembling the resources, or the value of the resource bundle was unappreciated by any of the parties when it was assembled.

If neither party appreciated the future value of the firm's reputation, then the resulting gain is clearly a windfall profit. However, it does not diminish the need for management to manage the "windfall resources" that arise from a windfall event. In fact, the ability to recombine resources in response to opportunities arising from windfall situations is itself an entrepreneurial act and the resultant profits may be considered a form of derivative entrepreneurial profit (i.e., derived from the windfall event). Thus, through a succession of windfall events, the value of a firm's portfolio of resources may grow over time, creating new opportunities for wealth generation. The ability of management to place these resources into new, more profitable, uses may itself become a key capability of successful organizations.
Consequently, as organizations grow, they become less dependent on strategic factor markets and more focused on managing internal resources. Paradoxically, this has the effect of giving an organization more bargaining power in strategic factor markets (Rajan and Zingales 1998).As discussed below, the ability to respond appropriately to shifts in bargaining power is itself a facet of expectations management.

\section{The Role of Expectations in the Entrepreneurial Process}

Much of the literature in entrepreneurship has focused on creativity or opportunity identification as the defining element in the entrepreneurial process (Shane and Venkataraman 2000). While the identification and decision to exploit an opportunity to create value are both necessary parts of the entrepreneurial process, they are not sufficient to generate wealth for the entrepreneur (Casson 1982). It is also necessary for the entrepreneur to acquire control over the relevant resources before any profits can be realized-a fact often overlooked in many entrepreneurship textbooks. Moreover, the discussion of expectations in the previous section indicates that the entrepreneur must acquire these rights for less than their future value to realize a profit.

\section{Defining Expectations Management}

Mintzberg (1987) once defined strategy as "... any pattern in a stream of decisions, whether intended or not." Similarly, expectations management may be conceived as any attempt to change opinions about the value of a resource, whether intended or not. This definition touches on several issues. First, the value of a resource is equal to the sum of the expected discounted cash flows to be derived from the resource over its life. Depending on the resource, this value may be capitalized in a single payment or paid periodically in the form of rent, wages, or interest. For instance, consider a world without inflation, risk, depreciation, time value of money, or exogenous shocks to supply or demand conditions. In this world, a factor owner would be indifferent to 10 payments of $\$ 1,000$ or one payment of $\$ 10,000$. In the first case, we would say that the resource is being rented, in the latter, that we are purchasing the resource. The purchase price (or capitalized value) is thus equal to the sum of the future rental cash flows.

In reality, the future is uncertain and therefore different economic agents will form different opinions about the future value of a resource. Each agent must form expectations about factors, such as the inflation, risk, time value of money, demand, and supply conditions, for various resource combinations. A divergence of opinion creates the possibility for entrepreneurial profit (or loss). Expectations management seeks to affect these opinions in a way that is favorable (i.e., more profitable) for the entrepreneur. 
The definition is silent on $w b o$ is managing expectations. When acquiring resources, a buyer would like to manage expectations down to a lower value whereas a seller would like to raise expectations. At various stages in an organization's life cycle, an entrepreneur will be both a buyer and seller of resources. As such, expectations management is similar to a negotiation, where two parties are attempting to discover a "zone of agreement" between two reservation prices. In the language of negotiation, expectations management attempts to shift perceptions of reservation prices. However, expectations management is more than negotiation. It is also about creating a climate in which stakeholders renegotiate agreements less frequently (usually because they are satisfied with existing arrangements). Notwithstanding the Microsoft DOS purchase, resource negotiations are not usually one-shot deals. Most entrepreneurs will face an ongoing attempt to manage the expectations of their stakeholders, particularly employees, customers, investors, and suppliers.

Finally, the definition recognizes that some managers and entrepreneurs may unconsciously be managing expectations and may actually deny that they have attempted to manipulate opinions and perceptions. As intent is difficult to measure, the definition focuses on outcomes; that is, whether there is evidence that expectations (and hence values) were changed as a result of an intervention. Often, the behavior may have to be inferred by comparing resource values (prices, capital values, wages, interest, rent) with companies that were not as successful in managing expectations. For instance, from its inception, Apple Computer positioned itself as the antithesis of IBM. IBM was the blue-suited corporate behemoth while Apple was the small, informal, hip, and user-friendly backyard start-up. Apple's advertising proclaimed it as "the computer for the rest of us." Both employees and customers at Apple were almost evangelical in their praise and endorsement of the machine. The result was that
Apple was able to attract a premium price from customers and hire (and motivate) some of the best programmers and designers in the computer industry (Carlton 1997). Clearly, Apple's strategy generated enormous profits for the company during the 1980s, and the return of Steve Jobs in the late 1990s has apparently reignited the company's culture and profits. But, is it expectations management? Jobs would probably argue that he did not intentionally seek to manipulate the expectations of his staff to acquire their talent at submarket rates; that they voluntarily put in the extra effort in response to his vision. However, many entrepreneurs have cultivated the talent to motivate people to volunteer resources from an early age. They may have come to associate this talent with positive labels such as leader, innovator, or visionary rather than derogatory terms, such as manipulator.

\section{The Entrepreneurial Process}

To effectively control a resource, an entrepreneur needs to acquire at least three rights (Barzel 1989):

1. the right to obtain income from the resource;

2. the right to direct the resource to different uses; and

3 . the right to alienate, sell or otherwise dispose of the resource.

This suggests that an entrepreneurial process focused on resource management (Stevenson, Roberts, and Grousbeck 1989) can be linked to the management of expectations (see Figure 1). Every stage in the process is associated with a critical management task and a set of expectations to be managed. Each stage, in turn, is discussed below.

\section{Identify}

The process begins with the identification of new, potentially profitable, resource combinations. Following Schumpeter (1934), this may involve the introduction of a new good; the

\begin{tabular}{|c|c|c|c|c|}
\hline & Identify & Assemble & Maintain & Release \\
\hline $\begin{array}{l}\text { Critical } \\
\text { Management } \\
\text { Task }\end{array}$ & Innovation & Coordination & Cooperation & Maximization \\
\hline $\begin{array}{l}\text { Critical } \\
\text { Expectations } \\
\text { to be Managed }\end{array}$ & Self & $\begin{array}{l}\text { Owners of: } \\
\text { physical capital } \\
\text { financial capital } \\
\text { human capital }\end{array}$ & $\begin{array}{c}\text { Stakeholders } \\
\text { (including customers, } \\
\text { competitors, suppliers, } \\
\text { employees) }\end{array}$ & Acquirer \\
\hline
\end{tabular}

Figure 1. An Entrepreneurial Process Based on Resource Management 
improvement of an existing good; the improvement of a production process; the opening of a new market; or the creation of a new organization. The key point is that the entrepreneur must somehow discern that the value of a resource bundle in some future use will exceed its value today.

The critical management task in the identification stage is creating a (creative) innovation. Creativity is "...the enabling process by which something new comes in existence" (Brazeal and Herbert 1999:39). The same authors define an innovation as the improvement in a product or process either through creativity or imitation (Brazeal and Herbert 1999). In their view, entrepreneurship is a creative act that leads to an innovation. Imitation, because it reduces, rather than increases, risk is not an entrepreneurial act.Thus, entrepreneurship must always involve creative innovation.

This is consistent with Schumpeter's (1934) view of the entrepreneur as the agent in society carrying out new, or novel, combinations and with Knight's (1921) view of the entrepreneur as the bearer of uncertainty.

During this stage, entrepreneurs must constantly struggle to manage their own expectations. The entrepreneur forms expectations about the future and, because of the inherent uncertainty involved in forecasting the future, there is always a danger that the expectations may be wrong.

As such, the single greatest threat facing an entrepreneur is that she may acquire resources that may be less valuable than originally thought. In particular, the entrepreneur may fall victim to the winner's curse; that is, the future value of the resources proves to be less than the initial outlay (Bazerman and Sameulson 1983). There is growing evidence that entrepreneurs are likely to have inflated expectations about the future (McGrath 1999). Research indicates that entrepreneurs are overconfident and prone to overgeneralize from a few characteristics or observations (Busenitz and Barney 1997). Entrepreneurs are also likely to perceive situations as less risky than others (Busenitz 1999). Arguably, the first battle entrepreneurs may have to fight is with themselves.

\section{Assemble}

Once the entrepreneur has identified a profit opportunity, she must assemble the appropriate resources to realize their hidden (at least to others) value. The ability to appropriate this future value is the essence of entrepreneurship (Stevenson et al. 1989). While some authors have chosen to label the establishment of a new organization as the "entrepreneurial event" (Gartner 1985), it is clear that the timeframe from value identification to value realization is indeterminate-ranging from seconds in financial markets to decades in industries such as pharmaceuticals and biotechnology.

The process of assembling resources is complicated by the need to shield the information about their future value from competitors and factor owners (Casson 1982). Obviously, if competitors become aware of the profit opportunity, then there is an incentive from them to preempt the entrepreneur and enter the market early. Moreover, the presence of multiple buyers in the strategic factor markets will tend to raise the price of the inputs, perhaps eroding the entire entrepreneurial profit in the process.

Even in the absence of competition, factor owners will still adjust their prices upwards if they suspect surplus value is being created. This is the primary reason that stocks trade at a premium following takeover announcements-existing stockholders surmise that a takeover would not be occurring unless the acquiring firm expected to improve the value of the acquired firm's resources. In fact, the evidence suggests that stockholders in acquired firms successfully manage to appropriate most of the value from a merger or acquisition (Datta, Pinches, and Narayanan 1992).

The entrepreneur has several avenues for obtaining control over required resources.These include: bootstrapping, or building on an existing stock of resources; engaging in financial exchange, including purchasing or renting a resource; and social exchange, where the right to use a resource is obtained through nonfiduciary means.

Bootstrapping, probably the most common form of resource acquisition, involves creating new resources from those already controlled by the entrepreneur. This includes using the family home as an office, using an employer's facilities for photocopying and computing, and using the family car to visit clients. The family home is often used as collateral to raise the financial capital needed to acquire other assets.

Entrepreneurs often find it difficult to attract capital through financial exchange because of the risk of failure, default risk, and difficulty in communicating information about the venture (Birley and Norburn 1985). Start-up firms suffer from a "liability of newness" and a "liability of size" that makes them much more likely to fail than established enterprises (Hudson and McArthur 1994). Lenders, creditors, investors, suppliers, skilled workers (and even customers) are therefore likely to either avoid a new venture or charge a premium for their services.

New firms also suffer from a lack of reputation, credibility, and creditworthiness (Larson 1992). Given higher credit default rates for new ventures, providers simply do not know whether a given firm will meet its commitments. This is particularly true whenever capital is being rented, as is always the case with human capital, where rent occurs in the form of wages. It is also common to rent property, equipment, and inventory, particularly when the entrepreneur lacks the financing to buy these items outright. The increased default risk ensures that the entrepreneur will pay a higher price for these services (if they can be obtained at all). 
Finally, entrepreneurs often find it difficult to communicate information about their opportunity to capital providers. Entrepreneurs must be careful not to release too much information because there is always the risk that the idea might be appropriated by factor owners (Teece 1986). In addition, ideas that are too radical might not be understood or believed by factor owners making them reluctant to commit their capital (Langlois and Robertson 1995).

The difficulty in establishing beneficial financial exchanges increases the importance of social exchanges in realizing potential opportunities (Larson 1992; Larson and Starr 1993; Hudson and McArthur 1994; Honig 1998). Personal reputation, for instance, may compensate for lack of firm reputation. Family or social networks may open up sources of capital, or create moral obligations, to supply resources at a reasonable price or extend credit on favorable terms. Trust is also easier to establish when a social bond is present (Lewicki, McAllister, and Bies 1998).

The ability to manage expectations is thus a critical aspect of the resource assembly phase. Clearly, the entrepreneur must change the characterization of the venture from disreputable, risky, and prone to failure to something more positive. All other things being equal, the negative perception of a new venture will ensure that the entrepreneur will pay a higher price to access resources than an established company. This places the entrepreneur at a competitive disadvantage and constrains the amount of profit that can be realized from an opportunity. These perceptions may even render otherwise profitable opportunities unprofitable. Any tactics that can increase the bargaining power of entrepreneurs would clearly be useful. We will consider several of these tactics in the next section.

The entrepreneur must also become adept at establishing social exchanges that will facilitate her own financial interests. The work of Maslow (1943) and others remind us that people have a wide variety of needs, only some of which are financial. Obviously, some of the difficulties in negotiating financial exchanges can be overcome if the entrepreneur can fulfill (or create an expectation that they will fulfill) some of these nonfiduciary needs in (full or partial) exchange for financial support.

Of course, once all the relevant resources have been acquired, the entrepreneur still has the challenging task of assembling and coordinating the resources under her control to actually realize the identified profit opportunity.

\section{Maintain}

Once the resources have been assembled and coordinated, they must be used to create an ongoing stream of products for sale and consumption. Resources must be maintained during this period of operation and there may be many threats to the value of the entity during this period.
Physical assets, for example, will suffer wear and tear and will need to be repaired or replaced. This is unproblematic if the asset is available in a competitive market but, if the asset is highly specialized to a particular task, there is a risk of holdup, where the factor owner appropriates some of the value-added (Williamson 1975, 1985). In fact, any resource that is being rented, or periodically acquired, on a factor market represents a potential holdup threat. While Williamson recommends acquiring ownership of specialized assets to avoid holdup, this is frequently impractical (for instance, mall retailers lack the financial capital to buy a shopping mall) or impossible (human capital cannot be owned). The ability to manage the claims and expectations of factor owners over time (including employees, suppliers, and creditors) will thus be critical for maximizing profit over the long run.

While holdup by factor owners is the most significant risk to profit diminution, it is by no means the only risk that organizations face. Organizations also face attacks on their value from a range of stakeholders, including customers, unions, governments, and the general community (Freeman 1984). Customers consistently seek lower prices, unions higher wages, governments more taxes and costly regulations, and the community more consideration. In turn, organizations invest in functions to manage the expectations of these groups: marketing, public relations, investor relations, and corporate affairs. The activities of these parts of the organization also fall legitimately within the study of expectations management particularly if they are aimed at preserving the value of the firm and minimizing the value claims and expectations of other groups.

The initial resource configuration assembled by the entrepreneur will need constant adjustment to respond to new opportunities and threats as they arise in the environment (Penrose 1959; Teece, Pisano, and Shuen 1997). Necessary adjustments include: adding new resources, placing existing resources in new uses and configurations, and forming alliances with complementary resource owners (Sanchez and Heene 1997).

While the venture remains small, the entrepreneur may be able to personally monitor environmental trends and developments. However, as the organization grows, opportunity identification must be delegated to subordinates (Greiner 1972). The total quality management (TQM) movement has always argued that employees should be involved in resource allocation decisions regardless of the size of the organization (Tonnessen and Gjefsen 1999). The power of delegated decision-making is also supported by recent work in complexity theory that finds that local optimization often outperforms global, top-down, management in complex environments (Stacey 1993; Kauffman, Macready, and Dickinson 1994; Kauffman 1995). 
A high level of trust within an organization encourages information exchange about opportunities; enhances organizational learning; and encourages risk taking and intrapreneurial behavior (Chung and Gibbons 1997). Conversely, a failure to garner cooperation from employees, to provide adequate incentives for innovative behavior, and to induce a "volunteer mindset" has the potential to lead to a suboptimal allocation of resources. This, in turn, makes the organization vulnerable to the "discipline of the market" including bankruptcy and takeover.

\section{Release}

Eventually, the entrepreneur will reach a point where resources must be released from the organization, either because of incremental changes in the environment (e.g., an economic downturn) or a more definitive change (e.g., an initial public offering or liquidation).

In an incremental scenario, resources that are rented (e.g., labor, property, and equipment) are usually easier to release from the organization than resources that are owned outright. In the process, however, the entrepreneur must be careful not to damage any existing stock of goodwill that might exist toward the organization (from customers, employees, or suppliers). Downsizing that is handled poorly may jeopardize the chance to acquire resources on favorable terms later on. Thus, the entrepreneur must be careful to manage the perceptions of the organization among stakeholder groups.

Seeking to dispose of assets (i.e., resources that are owned or created) changes the role of the entrepreneur from capital acquirer to capital provider. In this role, the entrepreneur attempts to maximize the apparent utility of the assets by working on the expectations of the acquirers. The entrepreneur knows that highly specialized assets will be difficult to sell (Williamson 1985) and that the value of an asset will be limited by the extent of the market (Smith 1776).Thus, whenever possible, the entrepreneur would like to convey the impression that (1) the assets can be deployed in a wide range of uses, (2) there is substantial interest from others in buying the assets, and (3) the potential value of the assets in alternative uses is high.

\section{Discussion}

The preceding discussion on the process of resource management has identified several target areas for the entrepreneur to manage expectations (see Table 1). Arguably, this list demonstrates that managing expectations is not a peripheral activity - it is absolutely essential to the realization of any entrepreneurial profit.

In one reading of the resource-based view (RBV), the ability to manage expectations is yet another organizational resource that is valuable, rare and difficult to copy (Barney, 1991). The same may also be said of an entrepreneur's negotiation skills or talent for impression management. Recently, however, theorists have attempted to move beyond the tautological nature of the RBV to explore the processes by which resources are accumulated (Sanchez and Heene 1997; Teece et al. 1997) and their value appropriated (Coff 1999). The current research adds to our knowledge by specifying the key role played by various forms of expectations management in the process of wealth generation.

Several other areas may also prove fruitful for future research. The role of public relations, employee relations, investor relations and marketing in managing expectations deserves more attention. Furthermore, the role of the firm in constructing reality to appropriate resources could probably be linked more closely with the literature on leadership and corporate culture (Rindova and Fombrun 1999).

Researchers may also be keen to collect empirical data on the management of expectations. In doing so they would need to generate measurement techniques for the various constructs that have been discussed. Initial studies could seek to concentrate on the frequency of usage of various expectations management techniques and the correlation between technique utilization and profits.

One of the challenges of expectations management (EM) is to define the boundaries of the approach. Questions such as where, when, and with whom will EM work have not yet

\section{Table 1. Targeted Areas for Action}

\begin{tabular}{ll} 
Process Area & Action. How do I? \\
\hline Identify & 1. Set realistic expectations about the value of an opportunity. \\
\hline Assemble & 2. Project confidence to overcome a fear of failure among investors. \\
& $\begin{array}{l}\text { 3. Project a reputable and trustworthy image. } \\
\text { 4. Offer to fulfill the intangible needs of stakeholders in return for financial support. }\end{array}$ \\
\hline Maintain & $\begin{array}{l}\text { 5. Avoid holdup by managing the claims and expectations of factor owners. } \\
\text { 6. Build trust in the organization to improve participation in opportunity identification and } \\
\text { implementation. }\end{array}$ \\
\hline Release & $\begin{array}{l}\text { 7. Maintain goodwill with stakeholders during downsizing exercises. } \\
\text { 8. Alter the perceptions of the acquisition value of the firm or asset. }\end{array}$
\end{tabular}


been addressed. Casson (1982) has argued that experienced businesspeople should be less susceptible to attempts to manage expectations than other groups although this awaits empirical verification. Also, empirical research is required to assess the relative contribution of EM to profitability.

Notwithstanding the results of empirical research, the field is unlikely to see universal strategies or rules for managing expectations. Like product and financial markets, factor markets constantly adjust prices in response to new information, including information on successful trading strategies. Consequently, it is unlikely that textbook strategies for managing expectations will be developed. Successful strategies will remain private and highly subjective (Kirzner 1973). General theories and post hoc analysis are likely to be the order of the day.

\section{Etbical Issues in Expectations Management}

Entrepreneurs may protest that the theory prescribes unethical behavior and projects them in an unflattering light, particularly when it goes against the prevailing myth of the entrepreneur as an innovator, job creator, and engine of economic growth (Nodoushani and Nodoushani 1999). Is EM an unethical practice that damages long-term venture viability or is it sometimes justified?

Gibson (1994) presents an interesting hypothetical in which an art dealer finds a very valuable old master at a garage sale for $\$ 10$. This is very similar to the DOS case presented at the start of this article. There are several views about the morality of these types of cases in the ethics literature. At one extreme is the golden rule-do unto others as you would be done by-in this case the art dealer should disclose all relevant information about the painting before the negotiation begins (Provis 2000). Most business ethicists see this solution as unrealistic and impractical. Provis (2000) suggests that, at the very least, the art dealer should indicate to the seller that the seller's knowledge is incomplete. Creating false beliefs or knowingly causing the seller to act in a way that she might regret is seen as morally wrong.

Other business ethicists argue that while it is always wrong to lie about material facts, it is reasonable to bluff about how much you are willing to pay, so long as the opportunity for mutual gain exists (Strudler 1995). In this view, Bill Gates was not acting unethically in the DOS deal because SCS was better off selling DOS than not selling it. A related school of thought argues that any form of deception (including deliberate misrepresentation or omission of pertinent facts) is morally regrettable because it wastes society's resources on protracted negotiations and inefficient deals. However, a person would not be morally wrong in using deceptive tactics, if not doing so would expose her to significant risks or costs (Dees and Cramton $1991,1995)$. Thus, it is not morally wrong for an intended vic- tim to lie to a potential murderer about her location. Using this line of thought, the art dealer should only pay $\$ 10$ for the painting because the seller is better off and the art dealer avoids the risk of losing the windfall profit to the seller.

Putting the two arguments together would suggest that all tactics to influence expectations are morally regrettable, but if both sides stand to gain from the exchange and the party with the superior information has a lot to lose if the information asymmetry is corrected, then it is not morally wrong to withhold information. This is sometimes referred to as the "self-defense" theory of business ethics (Strudler 1995). Expectations management is only unethical when lying (deliberately giving false information) or deception (deliberately omitting important information) results in a stakeholder being worse off than their initial position. This suggests that Gates acted ethically because he had a lot to lose if SCS became aware of his intentions and SCS still benefited from the deal.

The effect on an entrepreneur's reputation also has to be considered. If an entrepreneur acquires a reputation for deception, then potential stakeholders may not be willing to enter into future transactions with her. Some authors argue that it is always better to tell the truth because dishonesty degrades the firm's reputation, which destroys value in the long run (Cialdini, Petrova, and Goldstein 2004). However, the Microsoft case belies this theory; in fact, Gates may have acquired a reputation as a tough negotiator, which may have even improved Microsoft's long-term value (Weigelt and Camerer 1988). As a general principle, one-off negotiations will have less impact on reputation than repeated transactions with the same party. This suggests that expectations management should be utilized less in the maintenance phase of the resource management process. But even in the maintenance phase a stakeholder still has to become aware of the deceptive practices to become aggrieved and seek to renegotiate. The value of an individual's contribution can be very difficult to measure and, as we saw in the Apple case, employees may even be happy working longer hours and unaware of the "productivity gift" they are giving the company.

This does not mean that expectations management cannot be a win-win situation. In fact, we have argued that ethical EM always produces a win-win situation. However, win-win is not an objective in itself. It is only a useful strategy if it produces more profit for the entrepreneur (Gibson 1994). The art dealer and DOS cases illustrate that complete sharing of information does not always produce more personal profit for the entrepreneur.

\section{Conclusions}

Any opportunistic, profit-seeking entrepreneur must solve the problem of assembling resources for less than their expected future value. The identification of an opportunity, 
or the invention of a new product, is only the first step in wealth generation. Alexander Graham Bell may have invented the telephone but the idea was commercialized with financial support from two other partners, Thomas Sanders and Gardiner Hubbard, who recognized the future value of the investment (Brock 1981). Similarly, in our opening example, Bill Gates was able to manage the expectations of IBM and Seattle Computing Systems to generate enormous wealth for Microsoft without having invented the core prod- uct. The EM concept allows us to see that a common factor underlies a range of hitherto diverse entrepreneurial strategies and provides a new lens to view entrepreneurial behavior.

\section{Acknowledgments}

The author wishes to thank Gerardo Okhuysen, Lowell Busenitz, Greg Dess, Dev Jennings, and Guido Corbetta for their helpful comments on the original manuscript.

\section{References}

Barney, J. B. 1986. Strategic factor markets, expectations, luck and business strategy. Management Science 32: 10, 1231 -1241.

Barney, J. B. 1989. Asset stock accumulation and sustainability of competitive advantage: Reply. Management Science 35, 12: 1512-1513.

Barney, J. B. 1991. Firm resources and sustained competitive advantage. Journal of Management 17, 1:99-120.

Barzel, Y. 1989. Economic analysis of property rights. Cambridge: Cambridge University Press.

Bazerman, M., and W. Sameulson. 1983. The winner's curse:An empirical investigation. Lecture Notes in Economics and Matbematical Systems 213: 186-200.

Birley, S., and D. Norburn. 1985. Small vs. large companies:The entrepreneurial conundrum. The Journal of Business Strategy 6, 1:81-87.

Brazeal, D. V., and T.T. Herbert. 1999. The genesis of entrepreneurship. Entrepreneurship Theory E Practice 23, 3: 29-45.

Brock, G.W. 1981. The telecommunications industry: The dynamics of market structure. Cambridge: Harvard University Press.

Busenitz, L.W. 1999. Entrepreneurial risk and strategic decision making: It's a matter of perspective.Journal of Applied Behavioral Science 35, 3: 325-340.

Busenitz, L.W., and J. B. Barney. 1997. Differences between entrepreneurs and managers in large organizations: Biases and heuristics in strategic decision-making.Journal of Business Venturing, 12, 1:9-30.

Carlton, J. 1997. Apple: The inside story of intrigue, egomania, and business blunders. New York, NY: HarperBusiness.

Casson, M. 1982. The entrepreneur:An economic theory. Oxford: Martin Robertson.

Chung, L. H., P.T. Gibbons. 1997. Corporate entrepreneurship:The roles of ideology and social capital. Group E Organization Management 22, 1: 10-30.

Cialdini, R. B., P. K. Petrova, and N. J. Goldstein. 2004. The hidden costs of organizational dishonesty. Sloan Management Review 45, 3:67-73.

Coff, R.W. 1999. When competitive advantage doesn't lead to performance:The resource-based view and stakeholder bargaining power. Organization Science 10, 2: 119-133.

Datta, D. K., G. E. Pinches, and V. K. Narayanan. 1992. Factors influencing wealth creation from mergers and acquisitions:A meta-analysis. Strategic Management Journal 13, 1:67-84.

Dees, J. G., and P. C. Cramton. 1991. Shrewd bargaining on the moral frontier:Toward a theory of morality in practice. Business Ethics Quarterly 1, 2: 135-167.

Dees, J. G., and P. C. Cramton. 1995. Deception and mutual trust:A reply to Strudler. Business Ethics Quarterly 5, 4: 823-832.

Dierickx, I., and K. Cool. 1989. Asset stock accumulation and sustainability of competitive advantage. Management Science 35: 12, 1504-1511.

Freeman, R. E. 1984. Strategic management: A stakebolder approach. Boston, MA: Pitman.

Gartner,W. B. 1985. The conceptual framework for describing the phenomenon of new venture creation. Academy of Management Review 10: 696-706.

Gibson, K. 1994. Harmony, hobbes, and rational negotiation:A reply to Dees and Cramton's "promoting honesty in negotiation." Business Ethics Quarterly 4, 3:373-381. 
Greiner, L. E. 1972. Evolution and revolution as organizations grow. Harvard Business Review (July-August), $37-46$.

Hayek, F.A. 1945. The use of knowledge in society. American Economic Review 35: 519-530.

Honig, B. 1998. What determines success? Examining the human, financial, and social capital of Jamaican microentrepreneurs. Journal of Business Venturing 13, 5: 371-394.

Hudson, R. L., and A. W. McArthur. 1994. Contracting strategies in entrepreneurial and established firms. Entrepreneurship Theory \& Practice 18, 3: 43-59.

Kauffman, S. 1995. At bome in the universe: The search for laws of complexity. London: Penguin.

Kauffman, S., W. G. Macready, and E. Dickinson. 1994). Divide to coordinate: Coevolutionary problem solving (Working Paper 94-06-031). Santa Fe: Santa Fe Institute.

Kirzner, I. M. 1973. Competition and entrepreneurship. Chicago: University of Chicago Press.

Knight, F. 1921. Risk, uncertainty, and profit. New York: Houghton Mifflin.

Langlois, R. N., and P. L. Robertson. 1995. Firms, markets and economic change: A dynamic theory of business institutions. London: Routledge.

Larson,A. 1992. Network dyads in entrepreneurial settings:A study of the governance of exchange relationships. Administrative Science Quarterly 37, 1: 76-104.

Larson,A., and J.A. Starr. 1993.A network model of organization formation. Entrepreneurship Theory E Practice 17, 2: 5-15.

Lewicki, R. J., D. J. McAllister, and R. J. Bies. 1998. Trust and distrust: New relationships and realities. Academy of Management Review 23, 3: 438-458.

Maslow, A. H. 1943. A theory of human motivation. Psychological Review 50: 370-396.

McGrath, R. G. 1999. Falling forward: Real options reasoning and entrepreneurial failure. Academy of Management Review 24, 1:13-30.

Mintzberg, H. 1987. The strategy concept I: Five Ps for strategy. California Management Review 30, 1: 11-24.

Nelson, R. R., and S. G. Winter. 1982. An evolutionary theory of economic change. Cambridge, MA: Harvard University Press.

Nodoushani, O., and P.A. Nodoushani. 1999.A deconstructionist theory of entrepreneurship:A note. American Business Review 17, 1: 45-49.

Penrose, E. 1959. The theory of the growth of the firm. London: Basil Blackwell.

Provis, C. 2000. Honesty in negotiation. Business Ethics: A European Review 9, 1:3-12.

Rajan, R. G., and L. Zingales. 1998. Power in a theory of the firm. Quarterly Journal of Economics 113, 2: 387-432.

Rindova, V. P., and C. J. Fombrun. 1999. Constructing competitive advantage:The role of firm-constituent interactions. Strategic Management Journal 20, 8: 691-710.

Rumelt, R. P. 1987. Theory, strategy and entrepreneurship. In D. J.Teece, ed., The competitive challenge: Strategies for industrial innovation and renewal. Cambridge, Mass: Ballinger, 137-158.

Sanchez, R., and A. Heene. 1997. Reinventing strategic management: New theory and practice for competence-based competition. European Management Journal 15, 3: 303-317.

Schumpeter, J.A. 1934. The theory of economic development (R. Opie, Trans. first published 1911 ed.). Cambridge, MA: Harvard University Press.

Shane, S., and S. Venkataraman. 2000. The promise of entrepreneurship as a field of research. Academy of Management Review 25, 1:217-226.

Smith,A. 1776. An inquiry into the nature and causes of the wealth of nations. Oxford: Clarendon Press.

Stacey, R. D. 1993. Strategic management and organisational dynamics. London: Pitman Publishing.

Stevenson, H. H., M. J. Roberts, and D. E. Grousbeck. 1989. New business ventures and the entrepreneur, 3rd ed. Homewood, IL: Irwin.

Strudler,A. 1995. On the ethics of deception in negotiation. Business Etbics Quarterly 5 4: 805-822.

Teece, D. J. 1986. Profiting from technological innovation: Implications for integration, collaboration, licensing and public policy. Research Policy 15: 285-305. 
Teece, D. J., G. Pisano, and A. Shuen. 1997. Dynamic capabilities and strategic management. Strategic Management Journal 18, 7:509-533.

Tonnessen, T., and T. Gjefsen. 1999. The enterprise development: Direct employee participation in strategic planning. Total Quality Management 10, 4/5: 739-744.

Weigelt, K., and C. Camerer. 1988. Reputation and corporate strategy: A review of recent theory and applications. Strategic Management Journal 9: 444-454.

Wernerfelt, B. 1984.A resource-based view of the firm. Strategic Management Journal 5: 171-180.

Williamson, O. E. 1975. Markets and hierarchies. New York: Free Press.

Williamson, O. E. 1985. The economic institutions of capitalism. New York: Free Press.

\section{About the Author}

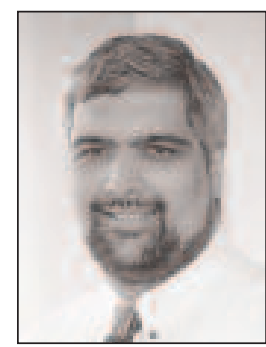

STEVEN E. PHELAN (steven.phelan@ccmail.nevada.edu) joined the faculty of the University of Nevada Las Vegas as an assistant professor of strategic management in July 2003 after previously holding positions at the University of Texas at Dallas and La Trobe University. Prior to joining academia, Dr. Phelan held executive positions in the telecommunications and airline industries and was a principal partner in Bridges Management Group, a consultancy specializing in strategic investment decisions.

Dr. Phelan has taught a combination of strategic management, entrepreneurship, organization theory, and change management courses for the last 12 years at various levels of instruction (undergraduate, MBA, EMBA, $\mathrm{PhD}$ ) on four continents. His eclectic range of research interests includes: the theory of the firm, complexity theory, game theory, Austrian economics, and critical theory. At the heart of his investigations lies a keen interest in how firms and entrepreneurs appropriate (or profit from) recognized opportunities. 